\title{
Chinese research status in emergency medicine journals: a bibliometric analysis based on Science Citation Index Expanded database
}

BY JU-FANG SHAO, XIANG-WEI YING, HUI-YUN SHEN

\section{Abstract}

Background. Emergency medicine in China has undergone tremendous growth. This study was conducted to evaluate the Chinese scientific output on emergency medicine in Science Citation Index Expanded (SCIE) in the Web of Science during the period of 2000-2013.

Methods. A bibliometric analysis was applied in this study. Articles published by China in SCIE emergency medicine journals were included. They were analyzed in terms of publication outputs, document type, language of publication, journals, countries/territories, institutions, and collaboration patterns. Distributions of article titles and keywords were also studied to reveal research focuses and trends.

Results. During the period, a total of 1043 articles from China were published in SCIE emergency medicine journals. Seven documents types 
were found, and the journal article was the most frequently used. All articles were written in English. The Hong Kong Journal of Emergency Medicine is the most productive journal. The most productive institutes were Prince Wales Hospital, followed by Tuen Mun Hospital, Chinese University Hong Kong; USA dominated the collaborative countries. The “injury/injuries", "trauma”, "acute”, "rat/rats", "arrest”, “emergency”, and "cardiopulmonary", "resuscitation" were the hot spots of emergency medicine research in China.

Conclusion. The results map emergency medicine (EM) development and research trends in China, and potentially guide Chinese EM physicians in evaluating and orienting their research.

Key words: emergency medicine, china, bibliometric, science citation index expanded, research

\section{Introduction}

Emergency medicine (EM) in China started in the 1980 s as an independent discipline. (1) Since then, EM in China has undergone tremendous growth. Up to now, emergency departments have been established in hospitals at different levels. At the same time, a large pool of specialists involving in clinical practice, research and teaching has been formed. Numerous studies (2-7) have been carried out on the various aspects of emergency medicine development in China; however, there is no report to analyze Chinese research status and trends in emergency medicine.

Bibliometrics, first introduced by Pritchard, are an effective method for analyzing scientific production and research trends. (8) As the most important and frequently used source database for the study of scientific output, the Science Citation Index Expanded (SCIE) database from the Web of Science had widely been used for bibliometric analysis of various fields. (9-14) Therefore, in this study, we used the bibliometric method to study the status of Chinese research and trends in emergency medicine journals based on SCIE database, during the period 2000-2013. The 
document type, language of publication, output of different journals, and collaboration patterns were analyzed. Distribution of article titles, and keywords were studied to reveal research focuses and trends.

\section{Materials and methods}

The data used in this study were derived from the database of SCIE, Thomson Reuters Web of Science, Philadelphia, USA. According to Journal Citation Reports (JCR) for 2014, it indexes 8474 journals with citation references across 176 scientific disciplines. There was a total of 25 journals in the Web of Science category of "emergency medicine". All articles from 2000 to 2013 with "Peoples R China" in the address field (updated March 1, 2014) were collected from the 25 EM journals. Articles only addressed in Taiwan were excluded from the study. Articles from England, Scotland, Northern Ireland, and Wales were reclassified as from the United Kingdom (UK). (15) The impact factor (IF) of each journal was collected from the JCR published in 2014. Contributions of different institutions and collaborated countries were estimated by the affiliation of at least one author to the article. Collaboration type was determined by the addresses of the authors (15): the term "China independent article" was assigned if authors were all from China; the term "institutional independent" was assigned if authors were from the same institution in China; the term "internationally collaborative article" was designated if authors were from China and other countries; the term "national collaboration" was assigned if authors were from different institutions in China. The included articles were analyzed in terms of publication outputs, document type, language of publication, journals, countries/territories, institutions, title words, and keywords. The included articles were downloaded in Microsoft Excel, and additional coding was performed manually.

\section{Results}


Research in emergency medicine in China started in the 1980s. Since then, publications from China can be found in international EM journals. The earliest six articles were entitled "Dehydration therapy and hypotension in post-resuscitation cerebral edema, and application of intraocular-pressure measurement - a review of resuscitation work .1." (16) in Resuscitation, "On the intracardiac use of combined adrenaline, isoprenaline and noradrenaline in the resuscitation of the heart beat - a review of resuscitation .2."(17) in Resuscitation, "Closed-chest intracardiac injection"(18) in Resuscitation, "Hemodynamic-studies of the effect of total alkaloids of datura in experimental hemorrhagic-shock in dogs"(19) in Resuscitation, "Large dose atropine alkaloids in the treatment of shock"(20) in Resuscitation, and "Experimental-study in rabbits of the antishock effect of anisodamine (654-2), and its mechanism of action" (21) in Resuscitation.

During the period 2000-2013, there was a total of 1043 articles published by Chinese authors in the Web of Science for the subject category 'emergency medicine'. The cumulative numbers of articles presented an increasing trend, as shown in figure 1. Only five papers were published in 2000, while the number of papers reached 195 in 2011, about 40 times of that in 2000. The fastest-growing period was from 2007 to 2008 , reaching a growth rate of $151 \%$. 


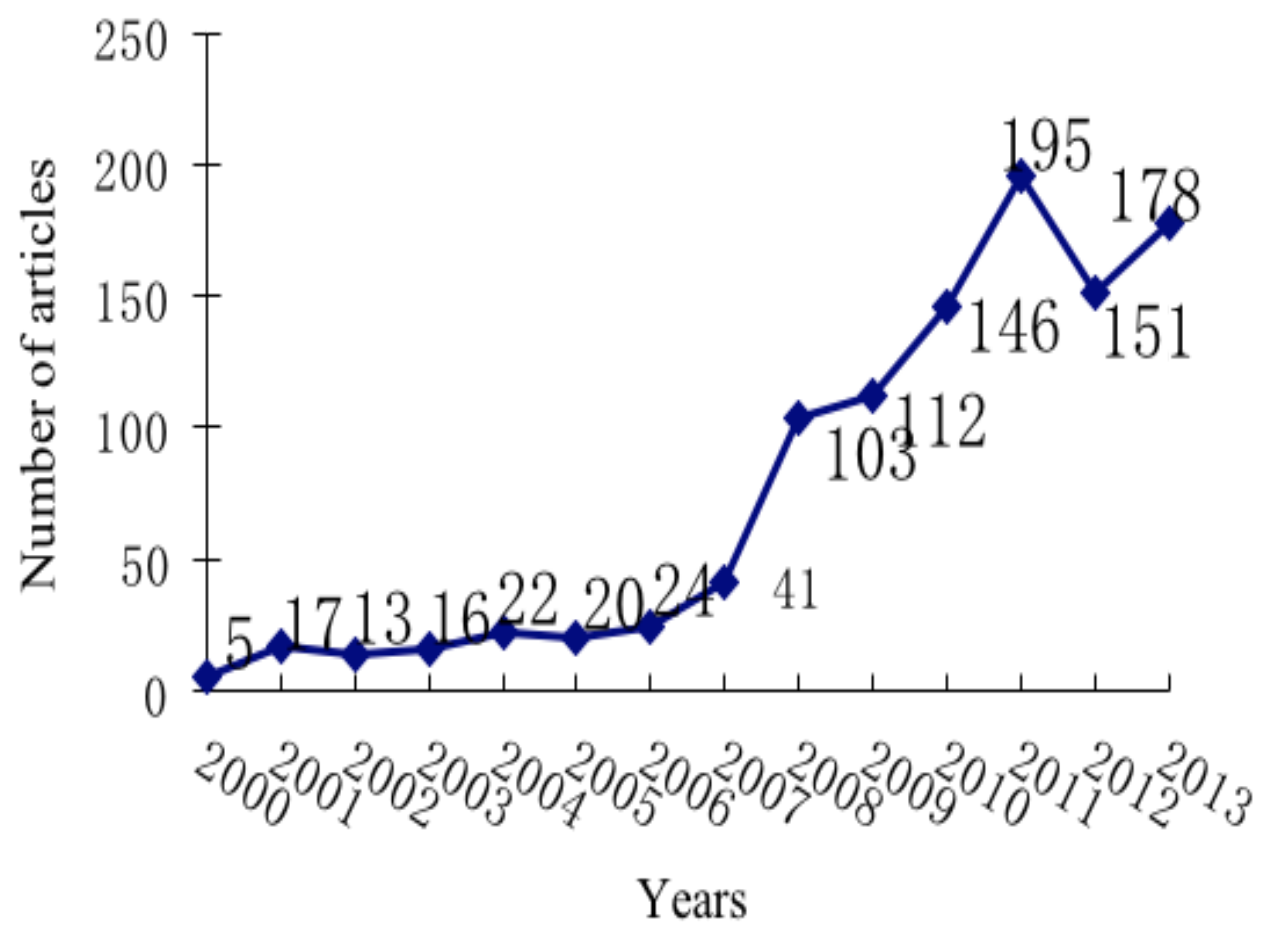

Figure 1. Cumulative number of articles during 2000-2013.

\section{Document type and language of publication}

According to the document type classification at the Web of Science, seven document types were found among the total of 1043 publications during 2000-2013. 'Journal article' was the most frequently used document type, with 754 articles, accounting for $72.3 \%$ of total productions. The other types were letters $(126 ; 12.1 \%)$, editorial materials (92; 8.8\%), reviews ( $41 ; 3.9 \%)$, meeting abstracts $(20 ; 1.9 \%)$, proceedings paper articles $(9 ; 0.9 \%)$ and corrections $(1 ; 0.1 \%)$. In this study, a total of 754 journal articles were extracted from the 1043 documents for further analyses.

Languages of all articles in this study were grouped. English was the only language used for all of these articles.

\section{Distribution of articles in journals}


There were 25 journals in the Web of Science (2014) category of 'emergency medicine'. Except Emergency Medicine Clinics of North America, Notarzt, Notfall \& Rettungsmedizin, and Prehospital Emergency Care, the remaining 21 journals published different numbers of articles from China.

Table 1. presents the numbers of articles being published by China, their impact factors in 2013, and impact factor ranks. It is noticed that Hong Kong Journal of Emergency Medicine (HKJEM) published the most Chinese articles (240), accounting for $23 \%$ of the total, followed by International Journal of the Care of the Injured (171; 16.4\%) and Journal of Trauma-Injury Infection and Critical Care (149; 14.3\%).

Table 1. Distribution of articles in journals found in the Web of Science category of 'emergency medicine' during 2000-2013.

\begin{tabular}{|c|c|c|c|}
\hline Journals & $\begin{array}{r}\text { TA } \\
(\%)\end{array}$ & $\begin{array}{l}\text { Rank } \\
\text { (IF } \\
\text { 2013) }\end{array}$ & $\begin{array}{l}\text { Journal } \\
\text { Country/Territory }\end{array}$ \\
\hline $\begin{array}{l}\text { Hong Kong Journal of } \\
\text { Emergency Medicine }\end{array}$ & $\begin{array}{l}240 \\
(23)\end{array}$ & $\begin{array}{l}25 \\
(0.154)\end{array}$ & $\begin{array}{l}\text { Peoples R } \\
\text { China }\end{array}$ \\
\hline $\begin{array}{l}\text { International Journal of the } \\
\text { Care of the Injured }\end{array}$ & $\begin{array}{l}171 \\
(16.4)\end{array}$ & $5(2.462)$ & England \\
\hline $\begin{array}{l}\text { Journal of Trauma-Injury } \\
\text { Infection and Critical Care }\end{array}$ & $\begin{array}{l}149 \\
(14.3)\end{array}$ & $3(2.961)$ & United States \\
\hline $\begin{array}{l}\text { American Journal of } \\
\text { Emergency Medicine }\end{array}$ & $\begin{array}{l}106 \\
(10.2)\end{array}$ & $\begin{array}{l}13 \\
(1.152)\end{array}$ & United States \\
\hline Resuscitation & $\begin{array}{l}97 \\
(9.3)\end{array}$ & $\begin{array}{l}2 \\
(3.960)\end{array}$ & Ireland \\
\hline $\begin{array}{l}\text { Annals of Emergency } \\
\text { Medicine }\end{array}$ & $\begin{array}{l}68 \\
(6.5)\end{array}$ & $1(4.333)$ & United States \\
\hline $\begin{array}{l}\text { Emergency Medicine } \\
\text { Journal }\end{array}$ & $\begin{array}{l}65 \\
(6.2)\end{array}$ & $9(1.776)$ & England \\
\hline
\end{tabular}


SIGNA VITAE 2016; 11(1):

\begin{tabular}{llll}
$\begin{array}{l}\text { European Journal of } \\
\text { Emergency Medicine }\end{array}$ & $\begin{array}{l}35 \\
(3.4)\end{array}$ & $\begin{array}{l}10 \\
(1.500)\end{array}$ & United States \\
\hline $\begin{array}{l}\text { Journal of Emergency } \\
\text { Medicine }\end{array}$ & $32(3.1)$ & $\begin{array}{l}12 \\
(1.175)\end{array}$ & United States \\
\hline $\begin{array}{llll}16 \\
\text { Pediatric Emergency Care }\end{array}$ & $16(1.5)$ & $\begin{array}{l}16 \\
(0.923)\end{array}$ & United States \\
\hline
\end{tabular}

Academic Emergency

Medicine

$13(1.3) \quad 6(2.198) \quad$ United States

Scandinavian Journal of

Trauma Resuscitation \&

Emergency Medicine

12 (1.2) $\quad 7$ (1.926) England

\begin{tabular}{|c|c|c|c|}
\hline $\begin{array}{l}\text { Emergency Medicine } \\
\text { Australasia }\end{array}$ & $\begin{array}{l}10 \\
(0.96)\end{array}$ & $\begin{array}{l}11 \\
(1.220)\end{array}$ & Australia \\
\hline $\begin{array}{l}\text { European Journal of } \\
\text { Trauma and Emergency } \\
\text { Surgery }\end{array}$ & $\begin{array}{l}9 \\
(0.86)\end{array}$ & $\begin{array}{l}21 \\
(0.380)\end{array}$ & Germany \\
\hline
\end{tabular}

Turkish Journal of Trauma 6

\& Emergency Surgery

$6 \quad 22$

(o.58) (o.379) Turkey

World Journal of

Emergency Surgery

$\begin{array}{lll}4 & 15 & \\ (0.38) & (1.062) & \text { England }\end{array}$

Journal of Emergency

Nursing

$3(0.3) \quad \begin{array}{ll}14 \\ (1.131)\end{array} \quad$ United States

Signa Vitae

$\begin{array}{lll}3 & 24 & \text { Croatia } \\ (0.3) & (0.173) & \end{array}$

Unfallchirurg

$\begin{array}{lll}2 & 19 & \text { Germany }\end{array}$

Canadian Journal of

Emergency Medicine

$1(0.1) \quad \begin{aligned} & 18 \\ & (0.660)\end{aligned} \quad$ Canada

Emergencias

$1(0.1) \quad \begin{aligned} & 4 \\ & (2.583)\end{aligned}$ 
IF 2013, impact factor in 2013; Rank, rank in order of impact factor in the Web of Science; TA (\%), total number and percentage of articles.

\section{Distribution of institutes and international collaborations}

Contributions of institutions were identified as the participation of at least one author. The 754 journal articles were distributed among 253 Chinese affiliations. A total of 647 (85.8 \%) articles were China independent publications and 107 (14.2\%) papers were international collaborations. Table 2 shows the top 20 institutes based on the number of papers. We found that 9 (45\%) institutes were from Hong Kong, followed by institutes from Beijing ( $3 ; 15 \%)$. Table 3 displays the top ten internationally collaborative countries, total number of articles collaborated with China, and the rank and percentage of first author articles and corresponding author articles. USA ranked first place, followed by Canada and Australia.

Table 2. Top 20 most productive institutes during the year 2000-2013.

Universities/Hospitals

Prince Wales Hospital

Tuen Mun Hospital

Chinese University Hong Kong

Beijing Chaoyang Hospital

United Christian Hospital

West China Hospital
TA Area
(\%)

90
(11.9) Hong Kong

64
$(8.5)$ Hong Kong

32
(4.2) Hong Kong

$\begin{array}{ll}25 & \text { Beijing }\end{array}$

25
$(3 \cdot 3) \quad H o n g ~ K o n g$

20 Sichuan

(2.7) Province 
SIGNA VITAE 2016; 11(1):

\begin{tabular}{|c|c|c|}
\hline $\begin{array}{l}\text { Chinese Peoples Liberation Army General } \\
\text { Hospital }\end{array}$ & $\begin{array}{l}20 \\
(2.7)\end{array}$ & Beijing \\
\hline Queen Mary Hospital & $\begin{array}{l}19 \\
(2.5)\end{array}$ & Hong Kong \\
\hline Queen Elizabeth Hospital & $\begin{array}{l}18 \\
(2.4)\end{array}$ & Hong Kong \\
\hline Third Mil Med Univ, Daping Hospital & $\begin{array}{l}17 \\
(2.3)\end{array}$ & Chongqing \\
\hline Shanghai Sixth Peoples Hospital & $\begin{array}{l}14 \\
(1.9)\end{array}$ & Shanghai \\
\hline Hebei Medical University, Hospital 3 & $\begin{array}{l}14 \\
(1.9)\end{array}$ & Hebei Province \\
\hline $\begin{array}{l}\text { Sun Yat-Sen University, Affiliated } \\
\text { Hospital } 1\end{array}$ & $\begin{array}{l}13 \\
(1.7)\end{array}$ & $\begin{array}{l}\text { Guangdong } \\
\text { Province }\end{array}$ \\
\hline Alice Ho Miu Ling Nethersole Hospital & $\begin{array}{l}13 \\
(1.7)\end{array}$ & Hong Kong \\
\hline University Hong Kong & $\begin{array}{l}13 \\
(1.7)\end{array}$ & Hong Kong \\
\hline Nanjing Jinling Hospital & $\begin{array}{l}13 \\
(1.7)\end{array}$ & $\begin{array}{l}\text { Jiangsu } \\
\text { Province }\end{array}$ \\
\hline $\begin{array}{l}\text { Pamela Youde Nethersole Eastern } \\
\text { Hospital }\end{array}$ & $\begin{array}{l}13 \\
(1.7)\end{array}$ & Hong Kong \\
\hline Beijing Union Medical College Hospital & $\begin{array}{l}12 \\
(1.6)\end{array}$ & Beijing \\
\hline Zhejiang University, Affiliated Hospital 2 & $\begin{array}{l}11 \\
(1.5)\end{array}$ & $\begin{array}{l}\text { Zhejiang } \\
\text { Province }\end{array}$ \\
\hline Shanghai Changhai Hospital & $\begin{array}{l}11 \\
(1.5)\end{array}$ & Shanghai \\
\hline
\end{tabular}

TA (\%), total number and percentage of journal articles.

Table 3. Top ten internationally collaborative countries/territories during the year 2000-2013. 


\begin{tabular}{lllll}
\multicolumn{1}{l}{ Country/territory TA } & $\begin{array}{l}\text { TAR } \\
(\%)\end{array}$ & $\begin{array}{l}\text { FAR } \\
(\%)\end{array}$ & $\begin{array}{l}\text { RAR } \\
(\%)\end{array}$ \\
\hline United States & 55 & $1(7.3)$ & $1(2.3)$ & $1(0.4)$ \\
\hline Canada & 14 & $2(1.9)$ & $5(0.3)$ & $2(0.3)$ \\
\hline Australia & 13 & $3(1.7)$ & $2(0.5)$ & $3(0.3)$ \\
\hline $\begin{array}{l}\text { United } \\
\text { Kingdom }\end{array}$ & 8 & $4(1.1)$ & $\begin{array}{l}4 \\
(0.4)\end{array}$ & $4(0.3)$ \\
\hline Italy & 8 & $5(1.1)$ & $3(0.5)$ & - \\
\hline Germany & 5 & $\begin{array}{l}6 \\
(0.66)\end{array}$ & $6(0.3)$ & - \\
\hline Israel & 3 & $7(0.4)$ & - & - \\
\hline Switzerland & 3 & $\begin{array}{l}8 \\
(0.4)\end{array}$ & - & $5(0.1)$ \\
\hline Norway & 2 & $9(0.3)$ & - & - \\
\hline Spain & 2 & $\begin{array}{l}10 \\
(0.3)\end{array}$ & - & - \\
\hline
\end{tabular}

TAR (\%), FAR (\%), RAR (\%), rank and percentage of total articles, first author articles, corresponding author articles in total articles; TA, total number of collaborative articles with China.

\section{Research emphasis and trend}

\section{Title-words analysis}

The title indicates what the article is about and distinguishes it from other articles. (22) An analysis of single words in the title could be used to make inferences of the scientific literature or to identify the subjective focus and emphasis specified by authors. (23) Therefore, in this study, all single words within the title of articles were analyzed. Some prepositions and common words such as "in" "of" "and" "with" "the" "a" "by" "for" "using" were excluded, as they have no usefulness for the analysis of research trends. The top 20 most frequently used single words in the title 
are listed in table 4 . We noticed that among the 784 article titles, "Injury/Injuries" ranked first, followed by "patient" and "emergency". These words showed a decreasing trend with the year of publication.

Table 4. Top 20 most frequently used single words in the title, 20002013.

\begin{tabular}{|c|c|c|c|c|}
\hline \multirow{2}{*}{ Words in titles } & $\begin{array}{l}2000- \\
2013\end{array}$ & $\begin{array}{l}2000- \\
2005\end{array}$ & $\begin{array}{l}2006- \\
2009\end{array}$ & $\begin{array}{l}2010- \\
2013\end{array}$ \\
\hline & $\mathrm{R}(\%)$ & R (\%) & R (\%) & $\mathrm{R}(\%)$ \\
\hline Injury/Injuries & $1391(18.4)$ & $1(1.9)$ & $1(4.8)$ & $2(11.8)$ \\
\hline Patient & $1302(17.2)$ & $1(1.9)$ & $3(3.2)$ & $1(12.2)$ \\
\hline Emergency & 953 (12.6) & $3(1.2)$ & $2(3.8)$ & $3(7.6)$ \\
\hline Fracture & 804 (10.6) & $4(1.1)$ & $7(2.5)$ & $4(7.0)$ \\
\hline Acute & $\begin{array}{ll}78 & 5(10.3)\end{array}$ & $7(0.8)$ & $4(2.8)$ & $5(6.8)$ \\
\hline Hong Kong & $656(8.6)$ & $7(0.8)$ & $5(2.7)$ & $7(5.2)$ \\
\hline Trauma & $607(8.0)$ & $5(0.9)$ & $9(2.3)$ & $10(4.8)$ \\
\hline Resuscitation & $598(7.8)$ & $11(0.4)$ & $10(2.1)$ & $6(5 \cdot 3)$ \\
\hline Rats & $58 \quad 9(7.7)$ & $9(0.5)$ & $5(2.7)$ & $12(4.5)$ \\
\hline Department & $55 \quad 10(7.3)$ & $5(0.9)$ & $7(2.5)$ & $16(3.8)$ \\
\hline Cardiac & $5311(7.0)$ & $13(0.3)$ & $13(1.7)$ & $8(5.0)$ \\
\hline Effect/s & $51 \quad 12(6.8)$ & $11(0.4)$ & $12(1.9)$ & $12(4.5)$ \\
\hline Model/s & $4913(6.5)$ & $19(0)$ & $11(2.0)$ & $12(4.5)$ \\
\hline Study/studies & $46 \quad 14(6.1)$ & $13(0.3)$ & $16(1.1)$ & $10(4.8)$ \\
\hline Treatment & $46 \quad 15(6.1)$ & $9(0.5)$ & $16(1.1)$ & $12(4.5)$ \\
\hline Arrest & $45 \quad 16$ (6.0) & $17(0.1)$ & $18(0.9)$ & $9(4.9)$ \\
\hline
\end{tabular}




\begin{tabular}{|c|c|c|c|c|}
\hline Traumatic & $38 \quad 17(5.0)$ & $13(0.3)$ & $14(1.5)$ & $18(3.3)$ \\
\hline Cardiopulmonary & $\begin{array}{ll}32 & 18(4.2)\end{array}$ & $17(0.1)$ & $15(1.3)$ & $20(2.9)$ \\
\hline Earthquake & $31 \quad 19$ (4.1) & $19(0)$ & $20(0.3)$ & $16(3.8)$ \\
\hline Clinical & $3020(4.0)$ & $13(0.3)$ & $19(0.8)$ & $19(2.9)$ \\
\hline
\end{tabular}

$\mathrm{R}(\%)$, rank and percentage of single words in title in total articles; TA, total number of articles.

\section{'Keywords plus' analysis}

Keywords plus provides additional search terms extracted from the titles of articles cited by authors in their bibliographies and footnotes in the ISI database. (24) Keywords plus may appear in articles that have no author keywords, or may include important terms that are not listed in the titles, abstracts, or authors keywords. Distribution of keywords plus in different periods has been used to provide further information for research trends. (25) The top 20 most frequently used 'keywords plus' were listed in table 5. The analysis of 'keywords plus' shows that similar to the results of author title-words, "injury/injuries", "trauma”, "resuscitation”, "acute", "rat/rats", "arrest”, "emergency", and "cardiopulmonary" were also hot spots in 'keywords plus' analysis; "injury/injuries" ranked first, followed by "management" and "trauma".

Table 5. Top 20 most used keywords, 2000-2013.

\begin{tabular}{|c|c|c|c|c|}
\hline \multirow{2}{*}{ Words in titles } & $\begin{array}{l}2000- \\
2013\end{array}$ & $\begin{array}{l}2000- \\
2005\end{array}$ & $\begin{array}{l}2006- \\
2009\end{array}$ & $\begin{array}{l}2010- \\
2013\end{array}$ \\
\hline & R (\%) & $\mathrm{R}(\%)$ & R (\%) & $\mathrm{R}(\%)$ \\
\hline Injuries/injury & $147_{(19.5)}^{1}$ & $1(1.6)$ & $1(3.8)$ & $\begin{array}{l}1 \\
(13.8)\end{array}$ \\
\hline Management & $76^{2}(10.1)$ & $3(0.7)$ & $2(3.1)$ & $\begin{array}{l}2 \\
(6.4)\end{array}$ \\
\hline
\end{tabular}


SIGNA VITAE 2016; 11(1):

\begin{tabular}{|c|c|c|c|c|c|}
\hline Trauma & 67 & $\begin{array}{l}3 \\
(8.9)\end{array}$ & $2(1.1)$ & $3(2.6)$ & $\begin{array}{l}4 \\
(5.2)\end{array}$ \\
\hline Care & 63 & $\begin{array}{l}4 \\
(8.4)\end{array}$ & $5(0.5)$ & $4(2.3)$ & $\begin{array}{l}3 \\
(5.6)\end{array}$ \\
\hline $\begin{array}{l}\text { Cardiopulmonary } \\
\text { resuscitation/CPR }\end{array}$ & 52 & $\begin{array}{l}5 \\
(6.9)\end{array}$ & $\begin{array}{l}14 \\
(0.1)\end{array}$ & $6(1.6)$ & $\begin{array}{l}4 \\
(5.2)\end{array}$ \\
\hline Acute & 49 & $\begin{array}{l}6 \\
(6.5)\end{array}$ & $\begin{array}{l}10 \\
(0.3)\end{array}$ & $9(1.5)$ & $\begin{array}{l}7 \\
(4.8)\end{array}$ \\
\hline Mortality & 49 & $\begin{array}{l}7 \\
(6.5)\end{array}$ & $7(0.4)$ & $\begin{array}{l}15 \\
(1.1)\end{array}$ & $\begin{array}{l}6 \\
(5.0)\end{array}$ \\
\hline Cardiac & 48 & $\begin{array}{l}8 \\
(6.4)\end{array}$ & $\begin{array}{l}14 \\
(0.1)\end{array}$ & $6(1.6)$ & $\begin{array}{l}8 \\
(4.6)\end{array}$ \\
\hline Arrest & 45 & $\begin{array}{l}9 \\
(6.0)\end{array}$ & $\begin{array}{l}14 \\
(0.1)\end{array}$ & $6(1.6)$ & $\begin{array}{l}10 \\
(4.2)\end{array}$ \\
\hline Cells & 43 & $\begin{array}{l}10 \\
(5 \cdot 7)\end{array}$ & $\begin{array}{l}10 \\
(0.3)\end{array}$ & $\begin{array}{l}17 \\
(0.9)\end{array}$ & $\begin{array}{l}9 \\
(4.5)\end{array}$ \\
\hline Shock & 43 & $\begin{array}{l}11 \\
(5 \cdot 7)\end{array}$ & $7(0.4)$ & $5(1.9)$ & $\begin{array}{l}11 \\
(3.4)\end{array}$ \\
\hline Expression & 33 & $\begin{array}{l}12 \\
(4.4)\end{array}$ & $3(0.7)$ & $\begin{array}{l}11 \\
(1.3)\end{array}$ & $\begin{array}{l}18 \\
(2.4)\end{array}$ \\
\hline Heart & 32 & $\begin{array}{l}13 \\
(4.2)\end{array}$ & $19(0)$ & $\begin{array}{l}15 \\
(1.1)\end{array}$ & $\begin{array}{l}12 \\
(3.2)\end{array}$ \\
\hline Rat/rats & 32 & $\begin{array}{l}14 \\
(4.2)\end{array}$ & $\begin{array}{l}10 \\
(0.3)\end{array}$ & $\begin{array}{l}13 \\
(1.2)\end{array}$ & $\begin{array}{l}13 \\
(2.8)\end{array}$ \\
\hline Child/children & 31 & $\begin{array}{l}15 \\
(4.1)\end{array}$ & $\begin{array}{l}14 \\
(0.1)\end{array}$ & $\begin{array}{l}11 \\
(1.3)\end{array}$ & $\begin{array}{l}15 \\
(2.7)\end{array}$ \\
\hline Emergency & 31 & $\begin{array}{l}16 \\
(4.1)\end{array}$ & $7(0.4)$ & $\begin{array}{l}13 \\
(1.2)\end{array}$ & $\begin{array}{l}17 \\
(2.5)\end{array}$ \\
\hline \multirow[t]{2}{*}{ Diagnosis } & 28 & $\begin{array}{l}17 \\
(3 \cdot 7)\end{array}$ & $5(0.5)$ & $\begin{array}{l}17 \\
(0.9)\end{array}$ & $\begin{array}{l}19 \\
(2.3)\end{array}$ \\
\hline & & 18 & & & 19 \\
\hline
\end{tabular}


Dysfunction

Survival

Risk
$28(3.7)$

$$
19(0)
$$

$9(1.5)$

(2.3)
20

(0.8)

19

(0.7)

CPR, cardiopulmonary resuscitation; TA (\%), total number and percentage of articles; R (\%), rank and percentage of each key words plus in total articles.

\section{Discussion}

In the present study, we observed that during the period 2000 to 2013, a total of 1043 papers articles were published, and the cumulative numbers presented an increasing trend. This increase indicates that Chinese authors are putting more effort into describing emergency medicine research than they formerly did. Meanwhile, the fast increase since the year 2007 is partly associated with the research assessment system and promotion system in China, in which SCIE papers play an important role. (26)

HKJEM is a biomedical publication of the Hong Kong College of Emergency Medicine and the Hong Kong Society for Emergency Medicine and Surgery. The editorial board members, editors, and peerreview team are located in, and mainly come from Hong Kong, China. Therefore, HKJEM published the most Chinese articles.

The analysis of institutes and countries indicate that 9 (45\%) institutes are from Hong Kong. This is partly related to HKJEM, which publishes mainly articles from Hong Kong. Besides, English is one of the official languages in Hong Kong, and is used widely in Government, academic circles, business and the courts. Therefore, compared with authors from mainland China, authors from Hong Kong have better English, and have less difficulty in writing English, which may help them to publish articles easier in international journals. 
As for the internationally collaborative countries/territories, USA ranked first place. The reason may be that since 1978/1979, China-U.S. academic exchange has become a steady trend. According to the Institute of International Education, the number of Chinese students in the United States rose to 1000 in 1980 , while in the 2012/2013 academic year, 235597 Chinese studied there. China-US academic exchange has been flourishing over the past 35 years. Currently, China is the leading place of origin for students going to the United States, while the United States is the second-biggest sender of students to China.

The results of article titles and keywords plus shows that "injury/injuries", "trauma”, "acute”, "rat/rats", "arrest”, “emergency”, and "cardiopulmonary", "resuscitation" were the hot spots of emergency medicine research in China.

Several limitations to this study warrant discussion. First, the analyses may be particularly susceptible to bias and error in determining eligibility and categorization of articles. A more comprehensive overview of emergency medicine research status in China would necessitate a systematic review of MEDLINE, EMBASE, and other medical libraries across a longer time frame.

In conclusion, the current study on China's research performance in emergency medicine journals in SCIE database demonstrates some significant points, which can help to map emergency medicine development and research trends in China, and potentially guide Chinese EM physicians in evaluating and orienting their research.

\section{Reference}

1. Pei YV, Xiao F. Emergency medicine in China: present and future. World J Emerg Med 2011 Dec;2(4):245-52.

2. Crowell R, Shao XH, Cummins RO. Emergency Medicine in China 1987. Ann Emerg Med 1988 Oct;17(10):1069-73.

3. Ali R. Emergency medicine in China: Redefining a specialty. J Emerg Med 2001 Aug;21(2):197-207. 
4. Hsu EB, Dey CC, Scheulen JJ, Bledsoe GH, VanRooyen MJ.

Development of Emergency Medicine administration in the People's

Republic of China. J Emerg Med 2005 Feb;28(2):231-6.

5. He J, Hou XY. The potential contributions of traditional Chinese medicine to emergency medicine. World J Emerg Med 2013 Jun; 4(2):92-7.

6. Lin GX, Luo YM, Cheng A, Yang SY, Wang JS, Goldman RD. Personal experience in pediatric emergency medicine training in Canada and China. Chin Med J (Engl) 2012 Oct;125(20):3747-9.

7. Li Y, Guo S, Xu S, Wang Z, Yu X. Emergency medicine in China: current situation and its future development. Am J Emerg Med 2012 Nov;30(9):2075-7.

8. Wang MH, Ho YS. Research articles and publication trends in environmental sciences from 1998 to 2009. Arch Environ Sci 2011;5:110.

9. Braun T, Schubert AP, Kostoff RN. Growth and trends of fullerene research as reflected in its journal literature. Chem Rev 2000 Jun;100(6):2475.

10. Baek S, Yoon DY, Min KJ, Lim KJ, Seo YL, Yun EJ. Characteristics and trends of research on positron emission tomography: a bibliometric analysis, 2002-2012. Ann Nucl Med 2014 Jun;28(5):455-62.

11. Wang Q, Yang Z, Yang Y, Long C, Li H. A bibliometric analysis of research on the risk of engineering nanomaterials during 1999-2012. Sci Total Environ 2014 Mar;473-4:483-9.

12. Cartes-Velasquez R, Delgado CM. Bibliometric analysis of articles published in ISI dental journals, 2007-2011. Scientometrics 2014 Mar;98(3):2223-33.

13. Tan J, Fu HZ, Ho YS. A bibliometric analysis of research on proteomics in Science Citation Index Expanded. Scientometrics 2014 Feb;98(2):1473-90.

14. Pan Y, Zhang Y, Gao X, Jia J, Gao J, Ma Z. Scientific progress regarding neural regeneration in the Web of Science: A 10-year bibliometric analysis. Neural Regen Res 2013 Dec 25;8(36):3449-54.

15. ChiuWT, Ho YS. Bibliometric analysis of homeopathy research during the period of 1991 to 2003. Scientometrics 2005 Jan;63(1):3-23. 
16. Chen HH. Dehydration therapy and hypotension in post-resuscitation cerebral edema, and application of intraocular-pressure measurement a review of resuscitation work .1. Resuscitation 1980 Sep;8(3):195-209.

17. Haohui C. On the intracardiac use of combined adrenaline, isoprenaline and noradrenaline in the resuscitation of the heart beat - a review of resuscitation .2. Resuscitation 1981;9:53-9.

18. Haohui C. Closed-chest intracardiac injection. Resuscitation 1981 Mar;9(1):53-9.

19. Zeng YM, Liu NH, Shen YT, Yang YF. Hemodynamic studies of the effect of total alkaloids of datura in experimental hemorrhagic shock in dogs. Resuscitation 1982 Jun;10(2):129-33.

20. Chen HH. Large dose atropine alkaloids in the treatment of shock. Resuscitation 1983 Feb;10(3):149-51.

21. Su J, Wu L, Tang C. Experimental-study in rabbits of the antishock effect of anisodamine (654-2), and its mechanism of action. Resuscitation 1983 Feb;10(3):173-84.

22. Article titles [Internet]. Wikipedia [cited 2014 December 26]. Available from: https://en.wikipedia.org/wiki/Wikipedia:Article_titles

23. Zhang GF, Xie SD, Ho YS. A bibliometric analysis of world volatile organic compounds research trends. Scientometrics 2010 May;83(2):477-92.

24. Garfield E. KeyWords Plus: ISI's breakthrough retrieval method. Part 1. Expanding your searching power on Current Contents on Diskette. Current Contents 1990 Aug;32(1):5-9.

25. Xie SD, Zhang J, Ho YS. Assessment of world aerosol research trends by bibliometric analysis. Scientometrics 2008 Oct;77(1):113-30.

26. Shao JF, Shen HY. Research assessment and monetary rewards: the overemphasized impact factor in China. Research Evaluation 2012 Aug;21(3):199-203.

Ju-fang Shao Editorial Office of World Journal of Emergency Medicine, the Second Affiliated Hospital of Zhejiang University School of Medicine, Hangzhou, China

Xiang-wei Ying Institute of Scientific and Technical Information of Zhejiang Province, Hangzhou, China 
of Zhejiang University School of Medicine, Hangzhou, China

Corresponding author:

Jufang Shao

World Journal of Emergency Medicine

Second Affiliated Hospital of Zhejiang University School of Medicine

88 Jiefang Road, Hangzhou 310009, P.R.China

Phone: 86-571-87783951

Fax: 86-571-87783647

E-mail: nancysjf@163.com

Article printed from Signa Vitae: http://www.signavitae.com

URL to article: http://www.signavitae.com/2016/o5/chineseresearch-status-in-emergency-medicine-journals-abibliometric-analysis-based-on-science-citation-indexexpanded-database/

Copyright (C) 2015 Signa Vitae. All rights reserved. 